\title{
LAW OF EVIDENCE E COMMON LAW: O SISTEMA DE PROVAS E O SIGILO NO DIREITO INGLÊS
}

\author{
LAW OF EVIDENCE AND COMMON LAW: THE SYSTEM OF EVIDENCE AND THE SECRECY IN \\ ENGLISH LAW
}

Gregório Edoardo Raphael Selingardi Guardia*

\begin{abstract}
Resumo:
Cada vez mais a normatização do Direito inglês atrai o interesse dos pesquisadores, especialmente, em virtude das possíveis aproximações entre os sistemas anglo-saxão e românico-germânico. Esta atual coexistência da Case Law e, do direito positivado dos statutes, não passa despercebida, também, no estudo do direito processual e do sistema probatório inglês. Destarte, propõe-se no presente artigo investigar se a natureza jurídica das noções historicamente consolidadas pelo Law of evidence inglês permanece inalterada. Trata-se, ainda, de identificar o caráter jurídico das modificações ocorridas no regime legal das regras de exclusão (exclusionary rules) e de suas respectivas modalidades (hearsay evidence, bad character testimony e illegal evidence). Com o exame, em seguida, dos principais meios de obtenção de prova no processo penal inglês (identificação criminal, busca e apreensão, interceptação telefônica e vigilância), à luz do reconhecimento histórico do direito fundamental à privacidade (Right of privacy) e do interesse estatal no sigilo das investigações criminais. Para tanto, indispensável à análise dos statutes e das decisões dos Tribunais ingleses e da Corte Europeia de Direitos do Homem.

Palavras-chave: Direito inglês. Law of evidence. Exclusionary rules. Sigilo na investigação criminal. Meios de obtenção de prova.
\end{abstract}

\begin{abstract}
:
Increasingly, the standardization of English law draws the interest of researchers, especially in view of the possible approaches between the Anglo-Saxon and RomanGermanic systems. This coexistence of current case Law and the statutes of positive law also do not go unnoticed in the study of procedural law and the english evidential system. Thus, this paper aims to investigate whether the legal notions historically consolidated by the english Law of evidence remains unchanged. It is necessary to identify the legal nature of the changes occurring in the legal exclusion rule and its modalities (hearsay evidence, bad character testimony and illegal evidence). Under the same approach, to examine the principal means of obtaining evidence in English criminal proceedings (criminal identification, search and seizure, interception and surveillance) in light of the historical recognition of the fundamental Right to privacy and the state interest in the secrecy of criminal investigations. Therefore, it is important to analyse the statutes and decisions of the english Courts and the European Court of Human Rights.
\end{abstract}

Keywords: English Law. Law of evidence. Exclusionary rules. Secrecy in criminal investigation. Methods of obtaining evidence.

Bacharel e mestrando em Direito Processual pela Faculdade de Direito da Universidade de São Paulo. 
1. Precedentes

O caráter histórico do Direito inglês é, certamente, uma de suas mais notáveis características. Se por um lado, os países seguidores do sistema românicogermânico valorizam o cunho lógico e racional de seus sistemas, o Direito inglês - que não conheceu a renovação pelo Direito romano, nem pelas codificações - desenvolveu-se de forma autônoma e sofreu limitadas influências do Direito continental.

A continuidade histórica do Direito é tratada pelo jurista inglês como produto de uma longa evolução, não interrompida por nenhuma revolução, exemplo inconteste "da grande sabedoria da Common Law, das suas faculdades de adaptação, do seu permanente valor, e de qualidades correspondentes nos juristas e no povo inglês". ${ }^{1}$

$\mathrm{Na}$ tradição jurídica inglesa o poder jurisdicional soluciona os casos concretos com base em precedentes. Contudo, se a solução para o caso presente não puder ser extraída de uma apreciação jurisdicional pretérita, um novo posicionamento será construído e a justificação empregada no julgamento estará alinhada à agregação dos argumentos utilizados para julgar aspectos semelhantes de casos anteriores. ${ }^{2}$

Em consonância com os ensinamentos de René David podem ser identificados quatro períodos principais na história do Direito inglês. Primeiramente, a época que precede a conquista normanda de 1066. Depois, o interregno entre 1066 e a dinastia dos Tudors (1485), espaço de formação da Common Law, no qual o direito costumeiro local é substituído por um único sistema comum a todo o reino. Na sequência, entre os anos de 1495 a 1832, desenvolve-se ao lado da Common Law, um sistema complementar (e algumas vezes conflitante), caracterizado pelas regras de equidade. ${ }^{3}$

No âmbito deste estudo interessa-nos, sobretudo, o quarto período, iniciado em 1832 e vigente até os dias atuais. Nesta etapa há um aperfeiçoamento sem igual das disposições normativas. A usual preocupação dos juristas ingleses com a disciplina processual - que até então prevalecera sobre a regulação do direito material - muda de sentido. A tradicional conceituação remedies precede rights passa a conviver com o agrupamento sistemático das soluções da Common Law.

O esforço clarificador e ordenador do quarto período está expresso na abrogação das leis em desuso e na superação de soluções arcaicas. No entanto, o labor legislativo realizado no século XIX não perverteu o aspecto tradicional do Direito inglês, de modo a aproximá-lo das codificações - permanece, portanto, a preponderância da obra dos Tribunais.

\footnotetext{
1 DAVID, René. Os grandes sistemas do direito contemporâneo. Trad. Hermínio A. Carvalho. São Paulo: Martins Fontes, 2002, p. 355.

2 GARCEZ RAMOS, João Gualberto. Curso de processo penal norte-americano. São Paulo: Revista dos Tribunais, 2006. p. 51.

3 DAVID, René. op. cit., p. 356.
} 
Não há ignorar que a sistematização do Direito inglês cada vez mais atrai o interesse da doutrina que, com frequência, aponta o movimento de uma aproximação com o Direito continental europeu. Fatores atraentes para a valorização das afinidades entre ordenamentos diversos, tais como a pauta do comércio internacional e a formatação de uma comunidade europeia, despontam como indicativos da integração também no Direito.

Intenta-se, pois, examinar se a significativa normatização das regras de exclusão do moderno Law of evidence, em alguma medida favorece o rompimento da Common Law com uma de suas características basilares, i.e., a prevalência dos precedentes dos Tribunais. Ou, se por outro giro, e a exemplo do que ocorreu no quarto período histórico do Direito inglês, as mudanças são, na verdade, aspectos conjunturais, e portanto, incapazes de inverter a metodologia indutiva da common $\mathrm{Law}^{4}{ }^{4} \mathrm{Com}$ o escopo de apurar as transformações, os esforços estarão concentrados na análise das exclusionary rules e dos meios de obtenção de provas no processo penal inglês.

\section{Considerações sobre o Law of evidence}

O estudo minucioso dos conceitos do moderno Law of evidence, notadamente pela relevância de aspectos histórico-culturais no aperfeiçoamento do Direito inglês, exige detida prospecção que, certamente, desborda dos limites deste trabalho. A investigação ora empreendida, menos abrangente, centra-se no exame teórico-conceitual, com vistas à identificação da natureza das recentes modificações na disciplina das exclusionary rules, bem como, na análise das eventuais consequências dessas mudanças de orientação.

Em razão dos objetivos propostos, indispensável breve incursão no funcionamento do processo penal inglês, sem que se pretenda, contudo, examiná-lo com toda abrangência. Assim, há que advertir, na exposição das generalidades deste tópico não se ignora a incompletude de tais anotações diante da complexidade do tema. Não se perca de vista, porém, a imprescindibilidade destas colocações para que mais à frente se possa indagar acerca dos novos rumos do Law of evidence.

Acentue-se, primeiramente, que no sistema jurídico anglo-saxônico a iniciativa instrutória do juiz no processo penal é sensivelmente restrita; característica convergente com o autêntico duelo travado entre partes processuais opostas. ${ }^{5}$ Se o mister

$4 \quad$ Para Gustav Radbruch: “La maniera inglese di pensare che ha acquisato specialmente con Francis Bacon un decisivo influsso, può essere contrassegnata con le parole: empirismo o induzione (Lo spirito del diritto inglese. Trad. Alessandro Baratta. Milano: Guffré, 1962. p. 8). Nas palavras de João Gualbero Garcez Ramos: "A diferença entre os sistemas de direito comum e o de direito continental é essencialmente metodológica. No primeiro caso, utiliza-se o método indutivo; no segundo o método dedutivo. Essa diferença entre as duas metodologias acabou por gerar, ao longo do tempo, particularidades de fundo. Mas a essência da diversidade é metodológica" (op. cit., p. 50).

5 ZILLI, Marcos Alexandre Coelho. Iniciativa instrutória do juiz no processo penal. São Paulo: Revista dos Tribunais, 2003. p. 94-95. 
da acusação é trazer à Corte testemunhas que sustentem a tese da culpa do imputado beyond any reasonable doubt, à defesa incumbe a demonstração da inocência ou do fracasso do órgão acusador em seu ônus probatório, por intermédio da apresentação da evidence pertinente, assim como pelo exame cruzado das testemunhas da acusação. ${ }^{6}$

O réu, por sua vez, pode tanto se pronunciar em favor próprio, como também se reservar o direito de permanecer em silêncio. Consoante John Smith, é característica dos sistemas inquisitoriais que o juiz dirija perguntas ao réu e às testemunhas, enquanto a acusação e a defesa procedem apenas a indagações adicionais. Nesse contexto, o juiz busca o descobrimento da verdade, enquanto nos sistemas acusatórios - como é o caso do Direito inglês - o magistrado permanece afastado da disputa, analisando a observância das regras do fair trial e o modo imparcial como a evidence deve ser apresentada aos jurados. ${ }^{7}$

A busca da verdade, ${ }^{8}$ tal como a faz um historiador, ${ }^{9}$ não compõe parte da cultura do Law of evidence. Nesse sentido, o objetivo do Processo Penal não é a investigação dos fatos ${ }^{10}$ ocorridos no passado, mas sim, o exame da comprovação da culpabilidade do acusado. Na tarefa, como diretriz, os jurados apreciarão a formação de plexo probatório que autorize a convicção do cometimento do crime beyond any reasonble doubt.

6 O ônus da prova no direito inglês comporta dois sentidos: (a) a obrigação de persuadir o tribunal da lei de que há evidences suficientes para que a decisão do tribunal do fato seja razoável (evidential burden). Se a Corte decidir que a acusação falhou na demonstração do evidential burden o caso deve ser paralisado e o acusado absolvido; (b) a obrigação de persuadir o tribunal do fato sobre a presença do necessário padrão de prova (legal burden). O padrão probatório (Standard of proof) é sempre o da comprovação dos fatos beyond any reasonable doubt.

7 SMITH, John. Criminal evidence. London: Sweet\&Maxwell, 1995. p. 1-2.

8 A inoportuna dicotomia entre verdade formal e material apenas afasta a sensibilidade do jurista para a única verdade possível: aquela atingível, contingente e construída à luz das autênticas garantias de verdade, quais sejam, o contraditório e a imparcialidade do julgador (GUZMÁN, Nicolás. La verdade en el proceso penal. Buenos Aires: Editores del Puerto 2006). Nesse sentido, Giulio Ubertis propugna como característica do sistema processual inquisitório, a busca pela verdade real, pois "non vingono, (...) limiti all' attività euristica del giudice." (Argomenti di Procedura Penale. Milano: Giuffrè, 2002, p. 6-7). O mesmo autor assinala que no modelo acusatório há uma complexa rede de regras de exclusão porque certos tipos de aquisição probatória são "ritenute inammissibili (...) l'accertamento della verità può essere perseguito solo attraverso un'opera di bilanciamento con gli altri valori che entrano in gioco nel compimento delle attività processuali" (op. cit., p. 10-11).

9 Sobre a analogia entre o historiador e o juiz, Michelle Taruffo assevera que ambos estão diante do problema de reconstruir um fato passado, de forma que surge para os dois a necessidade de fazer uso de provas que permitam o conhecimento indireto deste fato (TARUFFO, Michelle. La prueba de los hechos. Trad. Jordi Ferrer Beltrán. Madrid: Trotta, 2002. p. 336).

10 Para que a evidence seja admissível deve ser relevante para os fatos discutidos no processo. Os fatos em questão, em um processo criminal, são os que devem ser provados pela acusação, com vistas a estabelecer o cometimento do crime imputado, ou aqueles essenciais para a tese da defesa. Nas palavras de John Smith: "What facts are in issue, therefore, depends on the substantive law defining the elements of the crime and the elements of any defence which is raised. So, if the charge is murder, a common law offense, we look to the common law and we then find that prosecution must prove that: (i) the defendant D. killed P., (ii) by an act done with intend to kill, or with intent to cause serious bodily harm" (op. cit., p. 3-4). 
É, portanto, sob a inspiração deste sistema - acusatório e adversarial - que se denomina evidence a informação com a qual os fatos tendem a ser provados, e o Law of evidence, o conjunto das leis (Acts) e critérios reguladores dos meios com os quais os fatos podem ser provados. ${ }^{11}$

Em consonância com as diretivas da doutrina mais autorizada, há que se considerar, pois, a presença de uma única regra geral: toda evidence relevante é admissível, desde que não esteja sujeita a nenhuma exceção. ${ }^{12}$

\section{Atribuições do juiz e do júri}

A diferenciação entre Tribunal of law e Tribunal of fact é usual no Direito inglês. Enquanto o primeiro é competente para decidir questões sobre a admissibilidade e exclusão da evidence, ao segundo incumbe determinar o valor e a credibilidade da evidence. $^{13}$

Na Common Law compete ao juiz não apenas o controle da admissibilidade da evidence, mas também, o papel de direcionar o júri na sua apreciação. Impende que seja criterioso nas intervenções e que jamais indique ao júri o modo de decidir. ${ }^{14}$

Cabe ao juiz tecer as considerações que julgue apropriadas a respeito da prova oral produzida em juízo. A opção por alertar os jurados dependerá das circunstâncias do caso, do conteúdo e qualidade da evidence da testemunha; o que no mais das vezes será feito por intermédio da corroboration ou judicial note.

O conceito de corroboration pode ser expresso pela evidence oriunda de uma fonte independente. Em alguns casos, a evidence deve ser avaliada por mais de um meio para que a convicção seja sustentável. O Perjury Act de 1911 é exemplo contundente: uma pessoa não pode ser condenada por perjúrio com base na evidence de apenas uma testemunha. $\mathrm{O}$ alerta do juiz para que os jurados busquem a corroboration é conhecido como judicial warning.

11 A classificação da evidence, quanto à forma, compreende três modalidades: (a) Oral evidence: informações dadas pelas testemunhas para o júri ou para os juízes (a mais importante categoria nos casos criminais); (b) Documentary evidence: informação obtida pela leitura de documentos ou oitiva de gravações (a gravação é tratada como prova documental, assim como documentos escritos, mapas, gráficos, desenhos, fotos, cd's, tapes, filmes e negativos); e (c) Real evidence: tradicionalmente consiste nas inspeções de objetos e coisas realizadas pelos juízes leigos ou togados (como a suposta arma de um assassinato); ampliada esta categoria para abrigar evidences pré-judiciais, como câmeras de segurança e computadores inteligentes (SEABROOKE, Stephen; SPRACK, John. Criminal evidence and procedure: the essential framework. New York: Oxford University Press, 1996. p. 3-4).

12 KEANE, Adrian. The modern law of evidence. Oxford: University Press, 2008. p. 2.

13 Exceção seja feita aos summary trials, em que os juízes de paz determinam a admissibilidade e a credibilidade da evidence.

14 Para John SMITH: "The judge may never tell the jury that they must not acquit, but he may tell them that they may not acquit on a particular ground-i.e. on the ground of a defense to charge of which there is no evidence." 
Os fatos poderão ser comprovados independentemente do uso da evidence quando a existência destes seja tão óbvia que possam ser tidos como garantidos. $\mathrm{O}$ juiz, por meio da judicial note, indicará ao júri que trate o fato judicialmente noticiado como estabelecido. ${ }^{15}$

É responsabilidade do magistrado, instruir os jurados acerca da presunção dos fatos (presumptions of fact). Os fatos, em geral, devem ser demonstrados em conformidade com a disciplina da evidence. Excepcionalmente, contudo, alguns fatos são usados como prova ou admissão formal de outros, presumidos na ausência de evidence em sentido contrário. Exemplo típico faz-se aquele da intenção do agente - embora não estejam obrigados a inferir que o acusado pretendia ou previa as naturais e prováveis consequências de seus atos, o júri ou magistrado podem realizar tal inferência. ${ }^{16}$

$\mathrm{Na}$ chamada Presumption of regularity presume-se, na ausência de evidence em sentido contrário, que a execução de atos oficiais foi empreendida conforme a lei. Assim, se uma pessoa pretende agir na qualidade de juiz, oficial de polícia, etc., é presumido que foi devidamente nomeada. ${ }^{17}$

\section{Exclusionary rules}

A previsão de um conjunto especial de regras para as provas encontra justificativa no receio de que uma irrestrita apreciação do plexo probatório pelo júri resultasse no desvio dos imprescindíveis ideais de justiça da decisão. Desse modo, tanto para evitar vereditos irracionais, como para preservar os direitos do acusado, gradativamente, os precedentes dos Tribunais, consolidaram a disciplina das chamadas exclusionary rules.

O amplo rol de exclusão do moderno Law of evidence é reflexo da história da Common Law. Muitas destas normas são oriundas de períodos em que os juízes adotaram postura paternalista em relação aos jurados - era comum que a evidence relevante fosse

15 "The taking of judicial note, (...) is a matter to the court; indeed a judge will direct the jury to treat a fact which is judicially noticed as established. Examples of facts that have been judicially noticed are that the streets of London are crowded and that television is a common feature of ordinary domestic law". (SEABROOKE, Stephen; SPRACK, John. op. cit, p. 8)

16 As presunções de um fato, segundo a doutrina, seriam na verdade, circunstancial evidence. O conteúdo da evidence comporta três modalidades: (a) Direct evidence: diretamente se estabelece um fato em questão; (b) Circunstancial evidence: por meio da existência ou não de um fato poderá ser inferida; e (c) Collateral evidence: não sustenta os fatos direta ou indiretamente, mas é relevante para a credibilidade e admissibilidade de outras evidences (v.g.: se a única direct ou circunstancial evidence em um caso é dada por testemunha que se mostra notório mentiroso, o resultado pode ter como ponto principal uma collateral evidence).

17 A presumption of regularity expõe característica marcante do direito inglês, já propugnada por Gustav Radbruch, em meados da década de 30: a confiança do povo inglês em seu Direito, expressa na assertiva "we are a law-abbinding people". O autor, na obra O espirito do Direito inglês, expressa sua admiração pelo modo particular como despachada a bagagem nos trens ingleses: sem qualquer certificado o viajante coloca a valise no vagão próprio e depois a retira quando chega ao lugar de destino. 
excluída (v.g., hearsey evidence, evidence of character, opinion evidence of non-experts), pensando que os leigos poderiam superestimar seu valor e importância, ou até mesmo tratá-las como conclusivas. ${ }^{18}$

A exclusão da evidence visava nas origens, também, oferecer alguma proteção em favor do réu contra injustiças. Em uma época na qual o exercício da defesa contra acusações temerárias era pouco frutífero, os próprios julgadores passaram a formular e aplicar regras de exclusão no intuito de evitar a condenação de inocentes.

Ademais, os juízes ingleses sempre temeram a deliberada mistura ou fabricação da evidence apresentada aos jurados. Este fator justificou inclusive o banimento geral das afirmações feitas out of court por uma testemunha (hearsey evidence).

É de ser ressaltado, ainda, o papel das exclusionary rules na garantia da eficácia e concentração do juízo oral, assegurando o questionamento e a valoração em público da evidence. O contato direto dos juízes leigos com a evidence em muitos casos era imprescindível, até porque não se podia exigir dos jurados que valorassem documentos escritos, uma vez que muitos eram analfabetos.

Todavia, a pertinência das regras de exclusão é avaliada com algumas reservas. Sustenta-se, embora permaneça necessário prevenir que certo material seja colocado diante do júri, em razão do irremediável prejuízo ao acusado, a qualificação dos juízes leigos, por outro lado, vem amplamente aprimorada. Indaga-se, pois, se guiados pela clara e adequada direção do juiz togado, não poderiam valorar, e por iniciativa própria, relevar algumas modalidades de evidences.

A pertinência da reforma dos estatutos (statutory reform) está na pauta do dia do Direito inglês - esforços para alinhar o processo inglês à Convenção Europeia de Direitos Humanos. As paulatinas modificações já produziram consideráveis resultados direcionados à racionalização e clareza da lei e realce dos poderes discricionários do juiz. ${ }^{19}$

Desse modo, os critérios tradicionais de exclusão em um caso criminal se o valor probatório da evidence é inferior aos efeitos prejudiciais (v.g. hearsey e bad character testimony), ou se a evidence foi obtida ilegal ou impropriamente antes do julgamento - atualmente estão limitados por inúmeras exceções.

Destaque-se, em suma, ainda que as exclusionary rules espelhem uma cuidadosa construção dos precedentes no Direito inglês, não há nada de automático na exclusão de uma evidence. O efeito prejudicial ou a ilegalidade do modo como foi obtida

KEANE, Adrian. op. cit., p. 3.

19 Na comparação de Adrian Keane, o Law of evidence pode ser visto como uma máquina construída com base nos princípios da Common Law por "engenheiros" judiciais, mas que está sujeita a constantes reparos pelos "mecânicos" do Parlamento, responsáveis por redesenhar ou acrescentar novas partes à máquina. Aos juízes compete manter e calibrar a máquina, atividade que se sujeita a algumas restrições: os desenvolvimentos apenas ocorrem à medida que questões práticas são trazidas perante os Magistrados pelos litigantes. (op. cit., p. 3). 
não resultará necessariamente na exclusão, sendo imprescindível na hodierna sistemática, apreciação judicial que resultará na rejeição ou admissibilidade da evidence.

\subsection{Hearsey evidence (testemunhas de ouvir dizer)}

Segundo esta modalidade de exclusão, qualquer afirmação sobre um fato deve ser sustentada em juízo oral pela testemunha e in court, sob pena de ser inadmissível como evidence (dos fatos em questão). A regra aplica-se a todas as modalidades de alegações out of court, sejam orais, documentais, veiculadas implícita ou explicitamente.

Trata-se, na gênese, de verdadeira garantia em favor do imputado: exigese a presença das testemunhas em audiência pública e oral, excluindo-se a comunicação indireta, os boatos e rumores. Para que uma pessoa testemunhe, deverá fazê-lo sob juramento, diante do acusado e sujeita ao cross examination..$^{20}$

Para os Tribunais, a probabilidade de que as assertivas da hearsey evidence não sejam verdadeiras sempre foi acentuada; fator que justifica sua ampla exclusão. Depreende-se, aqui, autêntica desconfiança do Direito anglo-americano em relação às assertivas feitas out-of-court, bem como, quanto aos efeitos deletérios da apreciação desta evidence pelos jurados.

A despeito de se tratar de uma exclusionary rule desejável em princípio, inegáveis os problemas práticos que origina, justamente porque se exclui tanto a boa, como a má evidence, o que tem fomentado a criação de uma série de exceções a esta regra. Em especial, há que atentar aos frequentes riscos da condenação de um inocente ou da absolvição de um culpado. ${ }^{21}$

Os juízes da common law, no ensejo de minimizar alguns inconvenientes da regra da hearsey, sempre toleraram exceções à sua aplicação. Esta postura pode ser exemplificada pelo princípio da Res Gestae e pelo conceito de original evidence. ${ }^{22}$

De acordo com o princípio da Res Gestae, as afirmações feitas ao tempo do fato referido, quando descritivas de acontecimentos inseparáveis do ocorrido, são admissíveis como prova. ${ }^{23}$ Por outro lado, nos casos em que a afirmação out-of-court é

20 VOGLER, Richard. Últimas tendencias probatorias en Inglaterra: en especial, las reglas de exclusión. In: GÓMEZ COLOMER, Juan Luis. Prueba y proceso penal: análisis especial de la prueba prohibida en ele sistema español y en el derecho comparado. Tirant to Blanch, 2008. p. 406.

21 Emblemáticos alguns casos de erros judiciais na Common Law, que se referem tanto à possibilidade de absolver-se um culpado, como de condenar-se um inocente. Nesse sentido, Reino Unido vs Sparks: em 1964, um aviador branco norte-americano foi acusado de atentar contra o pudor de uma criança que, por sua tenra idade, não foi ouvida em juízo. Devido à regra do hearsay, à mãe da criança não foi possível dizer ao tribunal que, imediatamente após o delito, sua filha lhe havia dito que o criminoso era negro. E assim o aviador foi condenado.

22 A referência a duas exceções serve ao intuito de demonstrar a gradativa subversão do funcionamento da hearsay evidence - o número de ressalvas à regra tem se acentuado, a ponto de suscitar reflexões sobre o atual alcance e extensão de sua natureza.

23 KEANE, Adrian. op. cit., p. 118. 
empregada para corroborar a veracidade de uma alegação sustentada in court, tolera-se o emprego da hearsey evidence, por nesta hipótese se falar de uma original evidence. ${ }^{24}$

As soluções práticas da jurisprudência, voltadas à reparação dos desequilíbrios no uso indiscriminado da hearsey, enfrentam, porém, o desafio de não se difundir de forma incoerente ou contraditória. Por esta razão, surgiram iniciativas para estabelecer uma regulação sobre bases lógico-sistemáticas, favorecendo uma maior aproximação do sistema continental, tal como os conhecidos esforços de Lord Justice Auld no Direito inglês. ${ }^{25}$

No entanto, as recentes medidas dirigidas à instituição de equilíbrio e coerência na matéria da hearsey evidence não se pautaram pelos esforços de normatização da matéria. A adoção da sistemática da CEDH, por intermédio do Human Justice Act de 1998, favoreceu a criação de uma válvula de escape a ser usada discricionariamente pelos juízes: sempre que se tratar de interesse da justiça a hearsey pode ser admitida.

Diante das contradições geradas pelo propugnado crescimento de exceções a esta hearsey evidence, a solução adotada privilegia a força discricionária do juiz na avaliação da admissibilidade. Em razão desta escolha, é certo que não se há falar em prejuízo ao caráter adversarial da common law, como talvez se dissesse da opção de normatizar exaustivamente as hipóteses de exclusão.

Note-se, porém, ao repugnar soluções próprias da índole do Direito continental, em consonância com os esforços de preservação da racionalidade da common law, não se tem necessariamente o distanciamento dos dois sistemas. Ao contrário, a aproximação perpetua-se com base na crescente influência da $\mathrm{CEDH}$, representada pela mitigação do caráter imperativo das exclusionary rules, aspecto importante da preocupação do Direito inglês com a normativa comunitária europeia.

\subsection{Bad character testimony (testemunhas de caráter)}

O denominado bad character testimony institui a exclusão da prova com base no caráter, em eventuais condenações anteriores ou na suposta disposição do acusado para a reiteração delituosa. Cuida-se, pois, de evitar que um acusado seja julgado por crimes anteriores e impedir que a polícia cinicamente detenha os suspeitos habituais.

Esta exclusionary rule aplica-se a qualquer evidence que propicie condições para a inferência de que o acusado é culpado, justamente por ter agido de uma particular maneira no passado. A razão de ser da exclusão não se pauta na irrelevância do bad

24 SEABROOKE, Stephen; SPRACK, John. op. cit, p. 4.

25 Não há duvidar do considerável esforço, nos anos 90, para a consolidação da hearsay sobre as bases de uma lógica-sistemática. Spencer e Lord Justice Auld, reformadores radicais, privilegiaram o sistema continental para que a hearsay evidence fosse empregada quando se tratasse da melhor evidence disponível (VOGLER, Richard. op. cit. p. 408). 
character testimony. Busca-se, na verdade, tanto evitar uma valoração desproporcional desta evidence pelos jurados, como também, impedir a formação de uma convicção fundada em parâmetros irracionais.

Segundo a tradição do Law of evidence, os casos em que excepcionada esta regra têm como escopo utilizar a evidence para a demonstração da culpa ou inocência do acusado, em face dos fatos imputados. Todavia, não pode ser utilizada para comprometer a credibilidade do acusado como testemunha. ${ }^{26}$

Nas últimas décadas - a exemplo do que vem ocorrendo com outras modalidades de exclusionary rule - fomentou-se a reflexão sobre seu uso criterioso. A ponto de se poder aferir que com o advento do Criminal Justice Act de 2003, a regra preexistente foi invertida: as testemunhas de caráter são admissíveis agora quando satisfeitos certos critérios (ao invés de inadmissíveis com exceções). ${ }^{27}$

\subsection{Evidence ilegalmente obtida}

Em consonância com a tradição da Common Law, o juiz deve excluir a evidence quando considerar que seu valor prejudicial excede o valor probatório. Com o advento do Police and Criminal Evidence Act (PACE, 1984) - inspirado na teoria dos frutos da árvore envenenada - alargou-se o âmbito de proteção, dispondo a seção $78^{28}$, do Act, sobre a exclusão de toda unfair evidence.

Nada obstante a discricionariedade na exclusão da evidence ilegalmente obtida fosse empregada apenas em circunstâncias excepcionais na Common Law, a promulgação do Police and Criminal Evidence $A c t^{29}$ estabeleceu um regime estatutário

26 Sob a justificativa de que, quando o valor probatório é superior aos efeitos prejudiciais, a evidence pode ser admitida, o reconhecimento de pessoas (identity parades) sempre foi modalidade de obtenção de provas aceita no Direito inglês. Nunca se atribuiu, contudo, valor probatório muito significativo a esta evidence. Para a Common Law, a melhor evidence é sempre aquela feita in court, porém, a testemunha quando se referir a uma identificação passada estará remetendo a uma afirmação out-of-court. Por outro lado, a identificação realizada in court (dock identification) enfrenta a significativa desvantagem do decurso do tempo entre o crime e a identificação. Outras modalidades de reconhecimento de pessoas são a confrontation, vídeo $I D$, group ID e voice identification.

27 "En los procesos penales la prueba sobre el mal carácter del acusado solo es admisible si: (a) todas las partes están de acuerdo en admitir dicha prueba; (b) es propuesta por el propio acusado o en consecuencia de una respuesta dada a una pregunta suya en el interrogatorio cruzado; (c) es prueba explicativa importante; (d) es relevante en relación con una cuestión importante entre el acusado y el fiscal; (e) tiene valor probatorio sustancial en lo referente a una cuestión importante en los asuntos entre el acusado y un co-acusado; (f) es prueba para corregir una impresión falsa dada por el acusado; (g) el acusado ha hecho un ataque contra el carácter de otra persona.

28 "In any proceedings the court may refuse to allow evidence on which the prosecution proposes to rely to be given if it appears to the court that, having regard to all circumstances, including the circumstances in which the evidence was obtained, the admission of the evidence would have such an adverse effect on the fairness of the proceedings that the court ought to admit it."

29 As interceptações telefônicas, por sua vez, são reguladas pelo Interception of Communications Act (1985). A gravação ocorre apenas mediante mandado expedido pelo Ministério do Interior (diferentemente do 
completo para a fase de investigação na Inglaterra, representando autêntica guinada de sentido. Trata-se de documento sensivelmente orientado pelos Direitos Humanos. ${ }^{30}$

Há casos em que a Corte interrompe a exposição da evidence para examinar o modo como foi obtida (o denominado trial within a trial ou voir dire). O ônus da prova, em geral, incumbindo à parte que sustenta a admissibilidade da evidence.

O caso R.U. vs Khan, entretanto, trouxe à baila uma habitual invasão de domicílios pela polícia, visando instalar aparelhagens de escuta, com base em circulares do Ministério do Interior. Constatou-se, assim, que o Police and Criminal Evidence Act de 1984 não era suficientemente apto a impedir as diretivas do Ministério do Interior para a obtenção de evidences plenamente arbitrárias pela polícia.

Apenas com o Police Act de 1997 a interferência policial na propriedade ou nos cabos telefônicos tornou-se ilegal, quando desacompanhada de manifestação do Comissário Sênior das Interceptações. Tal medida deve ser de valor substancial na prevenção ou detecção de sérios crimes e restrita aos casos em não se possa razoavelmente empregar outros meios.

À luz da disciplina do Human rights Act de 1998 - documento voltado à efetivação das disposições da Convenção Europeia de Direitos do Homem - o ato de poderes investigatórios de 2000 é alvo de recentes criticas, tanto de juristas da Common Law, como do Direito continental. Sob o pretexto de combater o terrorismo, o Act de $2000^{31}$ diretamente afronta o entendimento da $\mathrm{CEDH}$, ignorando por vezes que a vigilância deve ser proporcional àquilo que se busca encontrar. ${ }^{32}$

que ocorre em outros países, compete ao Poder Executivo). O propósito da medida é o de prevenir ou detectar crimes graves, não sendo admissível no processo o uso das informações obtidas. A polícia, munida do mandado, pode realizar a interceptação em quatro casos: (a) quando detectado risco para a segurança nacional; (b) para evitar o cometimento de "sérios crimes" (ofensa que possa acarretar sentença de três anos de prisão, ou infração que envolva importantes interesses financeiros, ou praticada por um grande número de pessoas com um propósito comum); (c) se a segurança econômica do país estiver envolvida; e (d) se as autoridades do Reino Unido forem solicitadas com base em acordo de cooperação mútua para auxiliar na solução de sérios crimes acontecidos no exterior. As hipóteses (a), (b) e (c) são também previstas para o emprego do agente infiltrado e da vigilância invasiva (Ato de Poderes Investigativos de 2000).

30 Segundo o preâmbulo do Police and Criminal Evidence Act: “An act to make further provision in relation to the powers and duties of the police, persons, persons in police detention, criminal evidence, police discipline and complaints against the police; to provide arrangements for obtaining the views of the community on policing and for a rank of deputy chief constable; to amend the law relating to the Police Federation and Police Forces and Police cadets in Scotland; and for connected purposes."

31 O ato de Regulação dos Poderes Investigativos (2000) autoriza a chamada vigilância invasiva, que pode ser realizada em qualquer dependência residencial ou veículo privado, na presença da pessoa, até mesmo por meio de instrumento de vigilância.

32 SPENCER, J. R. O sistema inglês. In: DELMAS-MARTY, Mireille. Processos penais da Europa. Trad. Fauzi Hassan Choukr. Rio de Janeiro: Lumen Juris, 2005. 
O contexto da tomada de decisões sobre a prova é diverso nos países de Civil Law e Common Law. Para aqueles, ao contrário da Common Law, é habitual o pressuposto de que a prova jurídica não pode ser estudada por meio de uma noção ampla de prova, própria, por exemplo, de uma epistemologia geral, comum às ciências naturais. A prova no Direito, por essa vertente, exigiria noção especificamente jurídica. ${ }^{33}$

Michelle Taruffo é o autor da perspicaz concepção que diferencia as provas em sistema aberto (common Law) e fechado (civil Law). Como características desta última: a) todo o fenômeno das provas está compreendido nas normas que delas se ocupam, de modo que apenas interessa aquilo que está positivado; b) provas atípicas estão excluídas; c) a regulação jurídica da prova e o processo constituem um contexto autossuficiente e autônomo em relação a qualquer outro da experiência. ${ }^{34}$

Por outra vereda, a concepção aberta assim está representada: a) a prova é, sobretudo, um fenômeno que pertence à lógica e à racionalidade, de forma que alguns aspectos desse fenômeno estão previstos e regulados por normas; b) provas atípicas estão incluídas; c) as normas em matéria de provas não servem para definir e limitar o conceito jurídico de provas; posto que qualquer coisa serve para estabelecer um fato, sua utilidade maior é excluir a admissão de alguns meios de provas quando existente razão para tanto; d) é possível o emprego de noções, conceitos e modelos de análise provenientes de outros setores da experiência, sejam de caráter científico ou extraídos do sentido comum ou da racionalidade geral. ${ }^{35}$

É certo que o sistema da Common Law não se pauta, tradicionalmente, pela busca da verdade no processo. ${ }^{36}$ No entanto, na linha dos ensinamentos de Taruffo e Beltrán, a Common Law, ao proporcionar amplo recurso às metodologias e análises da epistemologia geral para a valoração da prova, significativamente favorece que a decisão adotada sobre os fatos corresponda à verdade. ${ }^{37}$

\footnotetext{
BELTRÁN, Jordi Ferrer, op. cit., p. 24-25.
}

La prueba de los hechos. Trad. Jordi Ferrer Beltrán. Madrid: Trotta 2002. p. 343-344.

35 TARUFFO, Michele. op. cit., p. 345. A divisão do autor em duas vertentes antagônicas de valoração da prova, bem como a comparação com o Civil Law e Common Law, faz-se em um sentido amplo, com vistas a diferenciar o padrão rígido de taxatividade sobre os meios de prova de seu oposto. Ou seja, a Common Law não espelha exatamente o protótipo de um sistema aberto (à medida que também possui leis em matéria probatória) e o Civil Law não representa perfeitamente um sistema fechado (visto que há receptividade de meios atípicos de prova).

36 A problemática com que nos deparamos não é se o processo deve ou não buscar a verdade dos fatos, ou se a verdade pode ou não ser alcançada em abstrato; mas sim, a compreensão de que a verdade dos fatos, estabelecida pelo julgador para constituir o fundamento da decisão, em nada é absoluta. Por isso, fala-se em verdade contextual e relativa: aquela que signifique a melhor aproximação possível atingida por meio de provas e com base nos fatos relevantes para a decisão (TARUFFO, Michele. op. cit, p. 522-525).

37 O contraditório e a imparcialidade são autênticas garantias de verdade do processo (GUZMÁN, Nicolás. op. cit., p. 137). Ambas as garantias encontram consistente respaldo no sistema adversarial. 
No Direito inglês a admissão de uma evidence em juízo não está condicionada à existência de uma norma permissiva, mas sobretudo, à sua relevância na dialética do contraditório. Nesse contexto, a evidence possui o atributo que para Taruffo constitui o próprio significado de prova: tudo aquilo que serve logicamente para provar um fato. A regra dos ordenamentos de Common Law, segundo a qual, todo elemento de prova relevante deve ser admitido, desde que não haja norma ou motivo específico para excluílo, deve ser compreendida não apenas como um princípio jurídico - principalmente, como princípio geral da razão.

Cumpre sublinhar, pois, as virtudes da Common Law ao recorrer às metodologias próprias da epistemologia geral para a valoração da prova, por se tratar de meio autorizado para incrementar as possibilidades de que a decisão adotada sobre um fato corresponda à verdade. As exclusionary rules, neste diapasão, cumprem a tarefa de excluir meios de prova relevantes, mas não têm o caráter de indicar quais evidences serão admitidas.

Em que pese a solidez do sistema adversarial inglês, a necessidade da disposição de leis em matéria probatória serviu significativamente para superar as revelhas soluções dos precedentes. A coerência e sistematização imposta pelo Law of evidence no quarto período do Direito inglês não significou, tal como afirmado anteriormente, uma inversão do modelo empírico e indutivo, mas sim, um ajuste contingencial da Common Law.

Igualmente, ao se constatar o avanço hodierno da normatização da evidence no Direito inglês, não há concluir pela subversão da tradicional racionalidade da Common $L a w$, mas reconhecer um esforço de adequação às diretrizes da Convenção Europeia de Direitos Humanos - labor que, inescusavelmente, perpassa por uma necessária disciplina legal para os meios de obtenção da prova.

O recente implemento do corpo normativo do Law of evidence, ainda que fortaleça uma aproximação com o sistema continental, não permite sustentar uma inversão de paradigma na Common law. A esta altura, mesmo com os significativas alterações na disciplina das exclusionary rules (tal como no bad character testimony ${ }^{38}$ ), o direito positivo não assumiu caráter preponderante. ${ }^{39}$

38 Acentua-se que a regra de exclusão das testemunhas de caráter a tal ponto sofreu alterações que suscitou indagação sobre a modificação de sua natureza: ao invés de se tratar de evidence geralmente excluída e admitida excepcionalmente, passou a ser evidence a priori, aceita desde que preenchidos certos requisitos.

39 Michelle Taruffo assevera que nos sistemas abertos a avaliação acerca da atipicidade da prova sequer é um levantamento pertinente, uma vez que é óbvia a resposta positiva. O autor afirma que as regras de exclusão não são propriamente uma técnica estranha ao civil law: uma boa parte das normas continentais tem o caráter de precluir uma prova que seria logicamente relevante. No entanto, há uma significativa diferenciação no conteúdo das provas havidas inadmissíveis, assim como uma regulação muito mais específica e complexa no civil law (op. cit. p. 345). À medida que a Common Law gradativamente afasta-se da concepção de um modelo de sistema aberto, os levantamentos característicos do sistema fechado passam a suscitar reflexões. Por tudo isso, não se pode afirmar que o tema da atipicidade probatória atualmente seja absolutamente 
6. Law of evidence e sigilo na investigação criminal

Como se sabe, a força vinculante dos precedentes jurisprudenciais na Inglaterra, o stare decisis, está no Direito comum consuetudinário, por isso a denominação Common Law. Se para a Civil Law a interpretação advém da norma ao caso concreto (criase o direito pela lei e o espírito da lei), na Common Law decorre do caso concreto a norma (cria-se o direito com base na vida jurídica e natureza dos fatos). ${ }^{40}$

É certo que na Common Law a interpretação jurídica é mais seguramente orientada pela natureza dos fatos - o caso singular porta em si já o seu direito (ex facto jus orictur). Todavia, a prevalência da noção de não antecipação do direito particular do caso concreto com ideias pré-constituídas, cada vez mais passa a conviver com o agrupamento sistemático das soluções da Common Law, os chamados statutes.

Por sua vez, o princípio da publicidade, no moderno due processo of law, representa meio de controle social do Poder Judiciário, autêntica garantia contra as possíveis arbitrariedades, a incrementar sensivelmente a confiança social na Justiça. A publicidade é exigência para o funcionamento da Justiça, à medida que viabiliza a responsabilidade social do juiz. Trata-se, portanto, de assegurar que a decisão judicial adotada se paute única e exclusivamente por critérios jurídicos. ${ }^{41}$

A publicidade, é cediço, reveste-se ainda de múltiplas funções: garantia do indivíduo ao escorreito exercício da jurisdição, que permite a fiscalização popular das instituições; efetiva possibilidade de defesa do imputado (contraditório), e garantia também de imparcialidade e independência dos juízes que não poderão ser acusados de desvio de conduta porque seus atos são transparentes.

Não se olvide, no entanto, a necessária imposição de determinado grau de sigilo no processo penal. Trata-se de limitar o acesso público a elementos e situações que possam ofender a intimidade de alguém ou o próprio interesse social, bem como de viabilizar a obtenção de elementos de prova indispensáveis à investigação.

Desse modo, com base no exame dos precedentes ingleses e nas normas do Direito positivo de regência (statutes), objetiva-se aferir o grau de extensão do sigilo dos atos persecutórios. Nesse sentido, cumpre perquirir as hipóteses em que assegurado o segredo das informações na investigação criminal, bem como, em que medida o Right of privacy deve ser entendido em situações complexas.

incipiente na Common Law.

40 Para Gustav Radbruch duas são as características essenciais deste Direito consuetudinário: o empirismo e a indução (Lo spirito del Diritto Inglese. Trad. de Alessandro Baratta. Milano: Giuffrè, 1962. p. 8).

41 GARCÍA, Antonio Del Moral; VIJANTE, Jesús Maria Santos. Publicidad y secreto en el proceso penal. Granada: Comares, 1996. Publicidad y secreto en el proceso penal. Granada: Comares, 1996. p. 7-8. 


\section{Noção de privacy no Direito Inglês}

A formulação de um modelo inglês de direitos fundamentais pode ser vislumbrada já no século XVII. Dentre as peculiaridades que o diferenciam do sistema continental, saltam aos olhos os relevantes fatores históricos que marcam a ininterrupta evolução desde o constitucionalismo medieval até os dias atuais. A continuidade histórica desse Direito, também conhecido como Law of the Land ou Law of England, é tratada pelo jurista inglês como produto de uma longa evolução não interrompida por nenhuma revolução. ${ }^{42}$

No modelo inglês, o reconhecimento dos direitos fundamentais é resultado da luta do povo pela restrição dos poderes régios, vislumbrada, sobretudo, nas disposições de documentos históricos. A Magna Carta de 1215, bem como as sucessivas Cartas de Direitos (Petition of Rights de 1628, Habeas Corpus Act de 1679 e Bill of Rights de 1689), evidenciam a convivência da dupla atuação parlamentária e judicial na Common Law, como freio contra o arbítrio do monarca. ${ }^{43}$

A própria redação do Bill of Rights suscita a memória das violações às liberdades do povo inglês. A formulação de um catálogo de proibições de determinadas ações da Coroa é o signo de que estamos diante de limitações ao poder régio. Nesse sentido, a transformação dos direitos estamentais em direitos dos indivíduos ingleses marca a chegada do Estado Liberal.

$\mathrm{O}$ direito à privacy no Reino Unido, em contraposição ao que ocorre no Direito Romano-Germânico, não tem status constitucional, em face da inexistência de Lei Maior escrita. As liberdades dos cidadãos são diretamente protegidas pelo Parlamento.

Silente o legislador, ainda assim restou amplamente difundida a noção de privacy na Common Law, datando do século XIX a célebre definição do juiz Cooley "the right to be left alone". Desde então passou a ser reconhecido o direito da pessoa de excluir qualquer ingerência estranha na vida privada; evidente o conteúdo negativo deste direito, que deve consentir a cada um o adequado isolamento moral para atingir a "peace of mind". ${ }^{44}$

Ao enfrentar a difícil tarefa de definir o conceito de privacy, a Comissão do Reino Unido (Committee on Privacy and Related Matters) elaborou a seguinte conceituação: "The right of the individual to be protected against intrusion into his

$42 \quad$ DAVID, René. op. cit., p. 355.

43 Como leciona Gregorio Peces-Barba Martinez, "son derechos consecuencia de la preocupación por limitar la prerrogativa regia”; diferentemente, portanto, de posturas pactistas influentes nas concepções jusnaturalistas racionalistas, que entendem a limitação da prerrogativa régia como consequência do reconhecimento dos direitos (Curso de Derechos Fundamentales. Madrid: Universidad Carlos III, 1999. p. 146-147).

44 BRANDEIS, Louis; WARREN, Samuel D. The right to privacy. Harvard Law Review, Boston, v. IV, n. 5, dez-1890. 
personal life or affairs, or those of his family, by direct physical means or by publication of information."

Hodiernamente, contudo, impõe constatar o caráter multidimensional deste direito. Da conceituação de um direito de conteúdo eminentemente negativo, cada vez mais se pensa a privacy não apenas como faceta do direito de estar só, mas também, sob o aspecto positivo do controle direto de informações e da capacidade de comunicá-las e mantê-las para si mesmo. Podemos falar, portanto, da aspiração a uma não circulação de informações pessoais, pretensão que consiste no interesse de apagar do domínio público, fatos desabonadores e filtrar a realidade por meio da revelação seletiva de fatos que concernem ao próprio indivíduo.

Com a incorporação da Convenção Europeia dos Direitos do Homem, por meio do Human Rights Act de 1998, o right of privacy passa a estar previsto expressamente no rol dos direitos e liberdades do cidadão.

\section{Sigilo na Investigação Criminal}

O Reino Unido tem sido reiteradamente acionado perante a Corte Europeia de Direitos Humanos, sob a acusação de violar a garantia do due process of law - especialmente a paridade de armas e a ampla defesa - por meio da aplicação de dispositivos legais e regulamentares que permitem ao órgão acusador manter em sigilo determinadas evidences, com fundamento no interesse público.

Em muitos casos, o escritório do Crown Prosecutor requer, antes da produção da prova da acusação em juízo, a manutenção do sigilo, em desfavor do próprio acusado, de parte dos elementos probatórios produzidos durante a investigação criminal. ${ }^{45}$

Tem-se sustentado, sem sucesso, nos Tribunais ingleses, o direito de ter reconhecida a violação dos direitos humanos estatuídos nos art. $6^{\circ}$, parágrafos $1^{\circ}$ e $3^{\circ}$ (direito ao processo equitativo), $8^{\circ}$ (direito ao respeito pela vida privada e familiar) e 41 (direito a reparação razoável), da Convenção Europeia de Direitos Humanos.

O Reino Unido vem defendendo a manutenção do sigilo de determinadas evidences, cuja divulgação seria prejudicial ao interesse público, seja por resultar em séria ameaça contra a vida de agentes e testemunhas, seja por prejudicar a investigação criminal em andamento contra outros suspeitos. O sigilo mostra-se elemento essencial para a proteção, não do Estado, mas da segurança da sociedade.

45 Apenas em 1985 foi criado o Crown Prosecution Service. Ao prosecutor (promotor) cabe promover a persecução penal perante as Cortes inglesas, tanto inferiores quanto superiores, sobretudo na tarefa de concluir o inquérito iniciado. Atualmente, a instituição está dividida em 42 unidades, correspondente à divisão da polícia (em Londres há 2 unidades policiais). As atribuições funcionais do Crown Prosecution Service encontram-se, contudo, sensivelmente limitadas: as decisões de iniciar o processo penal e de dirigir as investigações competem à autoridade policial; o direito de expor assuntos mais relevantes em juízo constitui monopólio dos advogados. 
Desde 1992, a Corte de Apelações da Inglaterra assentou que a acusação tem o dever de submeter ao controle judicial toda e qualquer decisão de acobertar elementos de prova, sob alegação de interesse público (public interest immunity), sem o que a persecução deve ser abandonada. Decidiu a Corte, mesmo em casos excepcionais, nos quais a natureza da prova impede seja a defesa notificada, a acusação deve peticionar ao juiz que, ex officio, pondere a necessidade de preservar-se o interesse público, em face dos interesses da justiça referentes à liberdade e à vida (balacing act). ${ }^{46}$

Atualmente, segundo as disposições do Criminal Procedure and Investigation Act de 1996, há uma exigência de controle judicial sobre a manutenção do sigilo e da notificação da defesa a respeito de toda informação relevante que, obtida na investigação, possa minar a tese da acusação.

Em face do propalado comprometimento da adequada preparação da defesa, tem-se pleiteado no Reino Unido, ao menos, a presença de um curador ad litem, com acesso amplo aos elementos informativos do inquérito. Trata-se de agente imbuído da missão de patrocinar os interesses do reclamante pela quebra do sigilo, sem contudo, ter para com o réu ou seu defensor, a obrigação ou sequer o direito de revelar o teor da evidence suprimida.

A Corte Europeia, por sua vez, vem assentando critérios para aferir se evidences da investigação criminal podem ser omitidas do réu. Os casos Jasper vs. the United Kingdom e Fitt vs. United Kingdom são emblemáticos. Em ambos os julgamentos os peticionários alegaram a ausência de oportunidade para conhecer e manifestar-se sobre as provas coligidas pela acusação. A possibilidade de ser decretado pelo Estado o sigilo sobre certos elementos de prova produzidos durante a investigação criminal não é contestada pela Corte, que admite como sua incumbência, velar pelo respeito ao contraditório (adversarial trial) e imparcialidade, assegurando o direito de conhecer e manifestar-se sobre as provas e alegações produzidas pela parte adversa. Em suma, tratase de assegurar o julgamento justo (fair trial). ${ }^{47}$

$\mathrm{Na}$ linha das advertências de John Spencer sobre os atuais desafios do processo penal inglês, aquele de proteger o investigado nas fases preliminares permanece irrealizado. O processo adversarial, por ser uma espécie de duelo, não pode funcionar de forma justa a não ser que as partes tenham igualdade de armas. Embora possível dizer que há igualdade na última fase do processo (audiência), é certo que não existe nas fases

$46 \quad$ A prática de descartar as fontes de prova não utilizadas para sustentar a denúncia até há pouco tempo era usual e não estava sujeita ao controle judicial. Todo material colhido sob a obrigação de manutenção de sigilo (documentos bancários, informações pertinentes à segurança nacional, informações que colocassem em risco testemunhas ou informantes) não era submetido à defesa, desde que esta supressão não fosse prejudicial à tese de defesa.

47 LESSA, Luiz Fernando Voss Chagas. Jasper vs. the United Kingdom. Revista Eletrônica do Ministério Público Federal, I, n. 1, 2009. p. 7-8. 
preliminares. Durante as investigações, nenhum personagem oficial tem o dever, nem o poder, de procurar elementos probatórios que interessem à defesa. ${ }^{48}$

A seguir, de rigor examinar os meios de busca de prova que servem à investigação, bem como perquirir se tais métodos, à medida que revelam detalhes acerca da intimidade e vida privada, são empregados de maneira condizente com as diretrizes da Convenção Europeia de Direitos Humanos.

\subsection{Identificação criminal}

A Royal Comission on Criminal Justice (1993) recomendou um registro nacional e maiores poderes para a polícia requerer dos suspeitos que forneçam amostras de DNA, a exemplo do que ocorre com as impressões digitais. Em 1994, o Governo britânico anunciou que o Reino Unido seria o primeiro a ter um banco de dados com estas informações. ${ }^{49}$

A Court of Appeal confirmou que a retenção de amostras de DNA e impressões digitais pela polícia, depois que um suspeito foi liberado do crime investigado, é compatível com os art. $8^{\circ}$ e 14 , da Corte CEDH. ${ }^{50}$

Embora a Court of Appeal reconheça que a retenção de impressões digitais e de amostras de DNA interfere no direito individual de respeito à vida privada, tal medida é justificada com base no art. $8^{\circ}$ (2) da Convenção, nos casos em que necessário prevenir a prática de crime. A seção 64, do Police and Criminal Evidence Act, permite a retenção de impressões digitais e amostras, após cumprida a finalidade para a qual foram tomadas, desde que tal evidence não seja usada para outros fins senão aqueles relacionados com a prevenção ou detecção de crime.

$\mathrm{O}$ argumento de que a retenção de impressões digitais e amostras do DNA no Police and Criminal Evidence Act não faz a distinção entre inocentes e condenados, contrariando o art. 14, da CEDH, também não vingou nos Tribunais ingleses. A Court

48 SPENCER, John. op. cit., 2005.

49 Segundo as autoridades britânicas, as informações serviriam tanto para auxiliar as investigações criminais, como também, para que uma pessoa cujo DNA conste na lista se abstenha de cometer outros crimes sexuais, em função do risco de ser identificada (DAVIES, Croall; DAVIES, Tyrer. Criminal Justice: an introduction to the criminal justice system in England and Wales. London: Longman, 1995. p. 97).

50 Consoante o art. $8^{\circ}$ : "1. Qualquer pessoa tem direito ao respeito da sua vida privada e familiar, do seu domicílio e da sua correspondência. 2. Não pode haver ingerência da autoridade pública no exercício deste direito senão quando esta ingerência estiver prevista na lei e constituir uma providência que, numa sociedade democrática, seja necessária para a segurança nacional, para a segurança pública, para o bemestar econômico do país, a defesa da ordem e a prevenção das infrações penais, a proteção da saúde ou da moral, ou a proteção dos direitos e das liberdades de terceiros. Art. $14{ }^{\circ}{ }^{\circ} \mathrm{O}$ gozo dos direitos e liberdades reconhecidos na presente Convenção deve ser assegurado sem quaisquer distinções, tais como as fundadas no sexo, raça, cor, língua, religião, opiniões políticas ou outras, a origem nacional ou social, a pertença a uma minoria nacional, a riqueza, o nascimento ou qualquer outra situação." 
of Appeal sustenta ser altamente indesejável e inadequado distinguir entre diferentes categorias de indivíduos cujas impressões digitais ou amostras tenham sido tomadas. Além disso, a discriminação alegada não estaria dentro de uma das categorias de discriminação referidas no art. 14 .

Para os grupos de defesa de Direitos Humanos, no entanto, a manutenção de amostras de DNA e impressões digitais, no âmbito do Police and Criminal Evidence Act, discrimina e rotula. Desse modo, as pessoas são consideradas inocentes mas persistem sendo investigadas pela justiça penal, o que resultará em um número desproporcional de inocentes com perfil de DNA nos bancos de dados da polícia, em especial, de todos aqueles que pertençam a minorias étnicas. ${ }^{51}$

\subsection{Busca e Apreensão (stop and search)}

O Police and Criminal Evidence Act (PACE) dispõe a respeito de três modalidades de buscas: em locais determinados; em pessoas ou veículos e pessoais intimas.

Induvidosamente, a polícia necessita de poderes para interpelar suspeitos e realizar buscas e apreensões quando presentes fundados indícios do cometimento de crime. Os cidadãos, por outro giro, são livres para realizar suas atividades cotidianas sem o risco de irrazoáveis abordagens nas ruas, ingresso arbitrário no domicílio ou prisões para averiguações.

A busca em local determinado é poder atribuído à polícia que impõe a expedição de mandado pelo juiz de paz. O Police and Criminal Evidence Act de 1984 (capítulo 1, seção I) permite à polícia efetuar busca em domicílios, sem o mandado nos casos de consentimento do proprietário, para recapturar fugitivo e para evitar situações de perigo ou crime.

No exercício desta faculdade investigatória não podem ser coletados os registros pessoais que a pessoa tenha adquirido ou criado no curso de qualquer contrato, negócio, ocupação profissional, ou para o propósito de qualquer trabalho remunerado ou sigiloso (como é o caso dos registros médicos); tecidos humanos ou fluídos corporais retirados para diagnóstico ou tratamento médico e que a pessoa mantenha em confidência; e material jornalístico confidencial que consista em documentos ou outras gravações. ${ }^{52}$

A seção 1, do Police and Criminal Evidence Act de 1984, atribui também à policia o poder geral de busca e revista, com base em fundada suspeita de bens ilegais carregados por pessoa ou em veículo, bem como na hipótese da prisão de suspeito durante

\footnotetext{
$51 \quad$ WOOD, Peter. Retencion of DNA samples does not infringe genetic privacy. Unites Kingdom Law Articles in English, dezembro de 2000. Disponível em: <http://vlex.com/vid/29348054>. Acesso em: 23 set. 2010.

52 SEABROOKE, Stephen; SPRACK, John. op. cit., p. 171.
} 
tempo razoável para busca. Os meios utilizados pela autoridade para encontrar a res são superficiais (vasculhar bolsos, mochilas, etc...), desautorizada a busca íntima realizada pelo policial.

O Code of Practice da polícia não estabeleceu parâmetros concretos de atuação do agente, situação que permite certa discricionariedade. As diretrizes para a realização do stop and search, no mais das vezes, baseiam-se, no mais das vezes, em critérios informais do próprio policial, como condenações anteriores que sejam de seu conhecimento; a manutenção da ordem e da autoridade policial e a suspeita geral (estar no lugar errado na hora errada)..$^{53}$

Salvo quando voluntárias, as buscas devem ser gravadas e o material há que permanecer disponível para o suspeito. A pessoa tem direito à notificação do nome do policial, da delegacia de polícia, do objeto procurado e do fundamento legal da medida. ${ }^{54}$

O Criminal Justice and Public Order Act de 1994 permite, contudo, exceções ao padrão mínimo de fundadas suspeitas, sempre que oficiais superiores de polícia acreditem haver incidentes envolvendo séria violência ou terrorismo. Esses poderes perduram por 24 horas, mas podem ser estendidos se crescentes os níveis de violência. Impõe advertir, também aqui, que a referida prática gera preocupação sobre a perseguição de certos grupos e minorias étnicas. ${ }^{55}$

O Police and Criminal Act confere o poder de proceder a buscas pessoais intimas e também de amostras de sangue, sêmen ou saliva de um suspeito. A busca íntima exige autorização do superintendente, que deve ter razoável grau de convicção acerca da ocultação de arma ou drogas. Apenas médicos ou enfermeiras qualificados estão autorizados a efetivar esta modalidade de busca pessoal.

\subsection{Interceptações telefônicas}

Diferentemente do que ocorre em outros países, a permissão para tais providências compete ao Poder Executivo, porque a gravação ocorre apenas mediante mandado expedido pelo Ministério do Interior. O propósito da medida é o de prevenir ou detectar crimes graves, não sendo admissível no processo o uso de informações obtidas como evidence. ${ }^{56}$

53 UGLOW, Steve. Criminal justice. London: Sweet\&Maxwell, 1995. p. 75.

54 As medidas estão associadas a outras providências adotadas à luz do Police and Criminal Evidence Act de 1984, reforma voltada à modernização e racionalização das práticas policiais. As providências eleitas, dentre outras, são: gravação de todos os depoimentos colhidos pela autoridade policial; a informação ao preso de seus direitos; comunicação com advogado e designação de causídico para os que não possuírem.

55 DAVIES, Croall; DAVIES, Tyrer. op. cit., p. 103.

56 A interceptação da correspondência também segue a mesma disciplina, segundo o Interception of Communications Act (1985). Segundo a seção 1(1) do Act de 1985, alguém que intencionalmente intercepta uma comunicação no curso de sua transmissão, por meio de um sistema de comunicação público, é culpado 
O caso Reino Unido vs Khan, entretanto, trouxe à baila uma habitual invasão de domicílios pela polícia, visando instalar aparelhagens de escuta, com base em circulares do Ministério do Interior. Constatou-se, assim, que o Interception of Communications Act (1985) não era suficiente para impedir arbitrárias diretivas do Ministério do Interior à polícia.

Apenas com o Police Act de 1997, a interferência policial na propriedade ou nos cabos telefônicos tornou-se ilegal, quando desacompanhada de manifestação do Comissário Sênior das Interceptações. Tal medida deve ser de valor substancial na prevenção ou detecção de sérios crimes e restrita aos casos em não se possa razoavelmente empregar outros meios.

A polícia, munida de mandado, pode realizar a interceptação em quatro casos: quando detectado risco para a segurança nacional; para evitar o cometimento de "sérios crimes" (indictable offences); se a segurança econômica do país estiver envolvida, e se as autoridades do Reino Unido forem solicitadas, com base em acordo de cooperação mútua, para auxiliar na solução de sérios crimes ocorridos no exterior. ${ }^{57}$

\subsection{Vigilância (Surveillance)}

O Parlamento quedou-se inerte na tarefa de regulamentar satisfatoriamente a vigilância. Esta prática policial é realizada, então, sem precisa disposição nos estatutos, pautando-se pelo princípio de Common Law: tudo que não é expressamente proibido pela lei é admissível.

Há uma limitada proteção estatuída no Interception of Communications Act de 1985, assim como na Lei de Proteção de Dados. Com efeito, o mais efetivo instrumento de controle parece ser a Convenção Europeia de Direitos do Homem, embora ainda existam sérias dificuldades para se lograr êxito na limitação destas práticas. $^{58}$

de um delito, salvo se efetuada a interceptação ao abrigo de um mandado emitido em conformidade com a lei.

57 As três primeiras hipóteses são previstas também para o emprego de agente infiltrado, vigilância invasiva e vigilância direta, segundo o disposto no Ato de Poderes Investigativos de 2000.

58 Sobre a condenação do Reino Unido por práticas policiais de vigilância violadoras dos art. $8^{\circ}$ e 13 , da $\mathrm{CEDH}$, notadamente o uso de aparelhagens de escuta e gravação em residências, vide Armstrong v. The U. K. (J. 16/07/2002), Elahi v. The U. K. (J. 20/09/1996), Chalkley v. The U. K. (J. 12/09/2003); em Hewitson v. The U. K., o recorrente contestou a legalidade da instalação e utilização pela polícia de um dispositivo de escuta secreta em seu local de trabalho. Por sua vez, em Wood v. The U. K. (J. 16/02/2005), a polícia realizou operação para prender suspeitos do cometimento de diversos delitos, detendo-os juntos em uma cela que tinha sido especialmente equipada com áudio secreto. Esperava-se que os suspeitos discutissem as razões da sua detenção e que a conversa pudesse incriminá-los. As evidences obtidas com base na escuta foram consideradas regulares pelos Tribunais ingleses, e os réus condenados. A Corte, ao apreciar a questão, considerou afrontados os art. $8^{\circ}$ e 13, da Convenção, sustentando que a constatação de violação é suficiente para a satisfação de qualquer dano moral sofrido pelo requerente. 
As orientações gerais para a utilização de equipamentos em operações de vigilância policial constam no Home Office Guidelines de 1984, cujo conteúdo não é estatutário. Em cada caso, o oficial superior deve certificar-se de que os seguintes critérios foram preenchidos: a investigação trata de crime grave; métodos normais de investigação foram tentados e falharam, ou pela natureza das coisas, mostraram-se inadequados para obter sucesso; devem existir boas razões para pensar que o uso do equipamento seria suscetível de conduzir a uma prisão e condenação ou para a prevenção de atos de terrorismo, e a utilização do equipamento há que ser operacionalmente viável. O responsável deve certificar-se que o grau de intrusão na privacidade das pessoas afetadas pelo sistema de vigilância é proporcional à gravidade da infração.

Com o advento do Ato de Regulação dos Poderes Investigativos de 2000 instituiu-se diferenciação entre as chamadas vigilâncias invasiva e direta. A primeira, em qualquer dependência residencial ou veículo privado, envolve a presença de uma pessoa no local, e é efetivada, por instrumento de vigilância. À sua vez, a vigilância direta concerne a todas as formas menos invasivas de vigilância. ${ }^{59}$

No entanto, contundente a crítica ao Ato de Poderes Investigativos de 2000: se o Human Rights Act de 1998, objetiva garantir maiores efeitos às disposições da Convenção Europeia de Direitos do Homem, o intuito de combater o terrorismo não justifica a mitigação das garantias do investigado. $\mathrm{O}$ critério frequentemente apontado de que a vigilância deve ser "proporcional àquilo que busca encontrar", parece ser insuficiente.

Atualmente há proliferação de câmeras de circuito fechado de televisão (CCTV) em centenas de vilas e cidades da Grã-Bretanha. As redes podem ser operadas por policiais, autoridades locais ou empresas privadas, e são em parte, financiadas por uma concessão do Home Office. Sua finalidade original era de prevenção e detecção da criminalidade, embora nos últimos anos tenham estas câmeras se tornado importantes ferramentas para a gestão do centro da cidade e do controle de "comportamento antissocial". Cerca de 150 milhões a 300 milhões de libras por ano são gastas na expansão da rede de 200 mil câmeras cobrindo os espaços públicos da Grã-Bretanha, mas os sucessivos governos têm relutado em aprovar leis específicas para disciplinar essa utilização. ${ }^{60}$

\section{Conclusão}

A comparação entre o sistema da Common Law e do Direito romanogermânico permite aferir as muitas qualidades do Direito anglo-saxão. Dentre estas, não

$59 \quad$ SPENCER, JOHN R. op. cit., p. 305.

60 Paranoia, Suspicion, Obsessive Surveillance - and a Land of Liberty Destroyed. By Stealth Daily Mail. Agosto de 2009. Disponível em: <http://vlex.com/vid/63220902>. Acesso em: 30 set. 2010. 
se ignore a certeza e segurança jurídica favorecida pelo sistema de precedentes, o grau de detalhamento do Case Law e a celeridade do processo.

A doutrina apresenta ainda outras virtudes que, conquanto não tenham sido objeto específico desta breve análise, podem ser acrescidas neste rol: a compatibilização da Common Law com o favorecimento da expansão econômica, bem como o fato de estar o acusado amplamente protegido contra a publicidade desfavorável.

Entretanto, mister ressaltar, diferentemente do que ocorre nos países de Civil law, as disposições sobre os poderes de polícia, o direito de prova, o procedimento diante dos Tribunais penais e os próprios poderes dos Tribunais ingleses estão distribuídos em dezenas de legislações especiais. O estado atual desses textos reflete a forma pela qual os ingleses pensam seu sistema: não se tem o hábito de pensar globalmente em termos de procedimento penal.

Valendo-nos das palavras de John Spencer, no Reino Unido, até o presente momento, não se pensou seriamente acerca dos direitos do Homem no processo penal. Com efeito, à medida que não se pensa globalmente em termos de processo penal, não se pensa na totalidade dos direitos que o processo deve atribuir ao acusado. ${ }^{61}$

Persiste para o jurista inglês o desafio de disciplinar os meios de obtenção de prova com maior detalhamento e rigor. Inadiável atentar, sobretudo, ao Ato de Poderes Investigativos de 2000, que institucionalizou as modalidades de vigilância invasiva, a pretexto, como se sabe, de combater o terrorismo.

São Paulo, junho de 2011.

\section{Referências}

BELTRÁN, Jordi Ferrer. La valoración racional de la prueba. Madrid: Marcial Pons, 2007.

BRANDEIS, Louis; WARREN, Samuel D. The right to privacy. Harvard Law Review, Boston, v IV, n. 5, dez. 1890 .

CHOUKR, Fauzi Hassan. Garantias constitucionais na investigação criminal. 2. ed. Rio de Janeiro: Lumen Iuris, 2001.

DAVID, René. O direito inglês. Trad. Eduardo Brandão. São Paulo: Martins Fontes, 2006.

DAVIES, Croall; DAVIES, Tyrer. Criminal Justice: an introduction to the criminal justice system in England and Wales. London: Longman, 1995.

DENNIS, Ian Howard. Statutes on evidence. Londres: Longman, 1990.

${ }_{61}$ SPENCER, John. op. cit., p. 97. 
DEU, Teresa Armenta. La Prueba Ilícita (Un Estúdio Comparado). Madrid: Marcial Pons, 2009.

DEZEM, Guilherme Madeira. Da prova penal: tipo processual, provas típicas e atípicas. Campinas: Milennium, 2008.

GUZMÁN, Nicolás. La verdade en el processo penal: una contribuición a la epistemologia jurídica. Buenos Aires: Editores del puerto, 2006.

INGMAN, Terence. The english legal process. 4. ed. Londres: Blackstone, 1992.

JONES, Carol A. G. Expert witnesses. Oxford: Claredon, 1994.

KEANE, Adrian. The modern law of evidence. Oxford: University Press, 2008.

HENDLER, Edmund S. La regla de exclusión en Inglaterra. In: Nueva Doctrina Penal. Buenos Aires: Editores Del Puerto, 2000. p. 253-268.

LESSA, Luiz Fernando Voss Chagas. Jasper vs. the United Kigdom. Revista Eletrônica do Ministério Público Federal, v. 1, n.1, 2009.

MITTERMAIER, C. J. A. Tratado da prova em matéria criminal. Trad. Herbert Wuntzel. 2. ed. Campinas: Bookseller, 1997.

RADBRUCH, Gustav. Lo spirito del Dirito Inglese. Trad. Alessandro Baratta. Milano: Giuffré, 1962.

RAMOS, João Gualberto Garcez. Curso de processo penal norte-americano. São Paulo: Revista dos Tribunais, 2006.

SEABROOKE, Stephen; SPRACK, John. Criminal evidence and procedure: the essential framework. New York: Oxford University Press, 1996.

SMITH, John. Criminal evidence. London: Sweet\&Maxwell, 1995.

SPENCER, John R. O sistema inglês. In: DELMAS-MARTY, Mireille. Processos penais da europa. Trad. Fauzi Hassan Choukr. Rio de Janeiro: Lumen Juris, 2005. p. 245-339.

TARUFFO, Michele. La prueba de los hechos. Trad. Jordi Ferrer Beltrán. Madrid: Trotta, 2002.

UBERTIS, Giulio. Argomenti di Procedura Penale. Milano: Giuffrè, 2002.

VOGLER, Richard. Últimas tendencias probatorias en Inglaterra: en especial, las reglas de exclusión. In: GÓMEZ COLOMER, Juan Luis. Prueba y proceso penal: análisis especial de la prueba prohibida en el sistema español y en el derecho comparado. Tirant to Blanch, 2008. p. 403-419.

ZILLI, Marcos Alexandre Coelho. A iniciativa instrutória do juiz no processo penal. São Paulo: Revista dos Tribunais, 2003.

WOOD, Peter. Retencion of DNA samples does not infringe genetic privacy. United Kingdom Law Articles in English, dezembro de 2000. Disponível em: <http://vlex.com/vid/29348054>. Acesso em: 23 set. 2010 . 